\title{
Radial polydactyly-revisiting its embryological, anatomical and etiological aspects
}

\author{
ANSARI, R. M. ${ }^{1 *}$ and KADIR, F. A. ${ }^{2}$ \\ ${ }^{1}$ Anatomy Discipline, Division of Basic Medical Sciences, Faculty of Medicine, Cyberjaya University College \\ of Medical Sciences, Jalan Teknokrat 3, Cyber 4, 63000 Cyberjaya, Selangor, Malaysia \\ ${ }^{2}$ Division of Human Biology, School of Medicine, International Medical University, No.126, \\ Jalan Jalil Perkasa 19, 57000 Bukit Jalil, Federal Territory of Kuala Lumpur, Malaysia \\ *E-mail: reshmaansari77@gmail.com
}

\begin{abstract}
Introduction: Radial polydactyly is a frequently encountered congenital anomaly. What is known less about this anomaly is its diverse etiology. In this situation, this article sheds more light on the embryology of the upper limb, the presentation, classification and a discussion on the varied etiology of radial polydactyly. Methodology: Review of various published literature from Scopus, PubMed central and Wiley's online library. Results: Latest research proves that the various expressions of Sonic hedgehog $(\mathrm{SHH})$ is responsible for this condition in addition to its varied etiology ranging from environmental factors, maternal diabetes and thalidomide embryopathy to chromosomal mutations. Pediatric surgeons have classified radial polydactyly into various subtypes in respect to its presentation and surgical outcomes. Conclusion: this paper is a concise review of radial polydactyly, exploring its anatomical, embryological and etiological aspects. It can be concluded that both genetic and environmental factors are culprits in the pathogenesis of radial polydactyly, but strong evidence pointing out the causal relationship between the environmental factors and Sonic Hedgehog expression is yet to be explored.
\end{abstract}

Keywords: radial polydactyly, sonic hedgehog, chromosome 7q26.3 mutation.

\section{Introduction}

In addition to the face, the only other part of the body that draws attention is the hand. Our upper extremities are responsible for daily life activities such as washing, dressing, feeding as well as for practicing hobbies such as sewing, playing musical instruments and drawing. Hence, congenital anomalies of the upper extremity are of high aesthetic and functional importance (WATT and KEVIN, 2009). A good functioning hand is essential for independent living (GRAINNE, 2010). Congenital anomalies affect 1\% to $2 \%$ of newborns, and approximately $10 \%$ of those children have upper-extremity abnormalities (KOZIN, 2003). Though worldwide prevalence is still not available, isolated researchers show that the prevalence of polydactyly was of $1.73 \times 1,000$ in alive newborns, where upper limb polydactyly exceeds that of the lower limb (PÉREZ-MOLINA, ALFARO-ALFARO, LÓPEZ-ZERMEÑO et al., 1993). The Polish registry noted the prevalence of sporadic polydactyly as $92.8 \%$ of which the hands had a strong predilection of $94.8 \%$ (MATERNA-KIRYLUK, JAMSHEER, WISNIEWSKA et al., 2013).

\section{Embryology of the Upper Limb with Respect to the Development of the Thumb}

Sonic hedgehog $(\mathrm{SHH})$, a diffusible morphogen, expressed by the notochord initiates the development of the limb bud composed of lateral plate mesoderm and somatic mesoderm into the overlying ectoderm (AL-QATTAN and KOZIN, 2013). As a result of this, the ectoderm bulges called as the apical ectodermal ridge (AER) approximately 26 days after fertilization. Out of the four zones (stylopod, zeugopod, mesopod and autopod) that develop in to the future upper limb, the zone which gives rise to the hand is the autopod. There is an undifferentiated progress zone (PZ) immediately under the AER. The autopod cells are the last to leave this PZ as the limb grows distally. As soon as the zones are established, the cartilage precursor cells and connective tissue precursor cells differentiate into the bones and muscles and tendons respectively. Initially the digital rays are fused (Day 41 of intrauterine life). Later apoptosis (programmed cell death) occurs in a distal to proximal fashion (Days 50-54 of intrauterine life) (AL-QATTAN and KOZIN, 2013). Specifically speaking, the thumb detaches from the other fingers as a sequence to division of all the other fingers at the eighth week of intrauterine life (SIQUEIRA, STERODIMAS, BORIANI et al., 2008).

Many transcription factors are involved in the patterning of the limbs in three direction, namely, proximodistal, anteroposterior and dorsoventral axes (AL-QATTAN and KOZIN, 2013). The development of the fingers is principally involved in the development of the anteroposterior axis. $\mathrm{SHH}$ in the $\mathrm{ZPA}$ is responsible for the symmetrical and structural identity of the hand, wrist and forearm. The area around $\mathrm{SHH}$ is divided into three zones as shown in Figure 1.

The structures developing form these three zones are shown in the following Table 1 (summarised from AL-QATTAN and KOZIN, 2013).

Thus, the thumb develops from Zone III which, in contrary to other zones develops only in the absence of SHH. Apart from the absence of $\mathrm{SHH}$, the development of Zone III occurs under the influence of other factors such as mesodermal 
Table 1. showing the structures developing from the three zones of the hand.

\begin{tabular}{|c|c|c|}
\hline Zones & Structures that develop from the zone & Factors involved \\
\hline I & $\begin{array}{l}\text { Ulna, the little finger, the ring finger, the ulnar half } \\
\text { of the middle finger, and the ulnar } 2 \text { columns of the } \\
\text { carpal bones }\end{array}$ & Descendants of SHH-expressing cells \\
\hline II & Radial part of the middle finger and the index finger & Influence of long-range SHH signalling \\
\hline III & $\begin{array}{l}\text { Radius, the radial column of the carpal bones, and the } \\
\text { thumb }\end{array}$ & $\begin{array}{l}\text { Absence of SHH activity and influence of other } \\
\text { factors such as mesodermal SALL4 and HOXAl3 and } \\
\text { ectodermal FGF8 }\end{array}$ \\
\hline
\end{tabular}

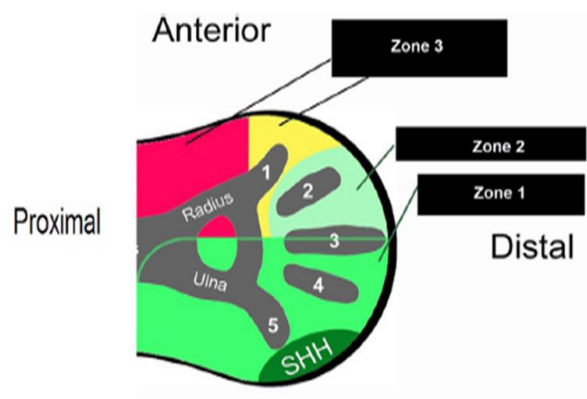

\section{Posterior}

Figure 1. shows the three zones of hand development (AL-QATTAN and KOZIN, 2013).

SALL4 and HOXA13 and ectodermal FGF8 (AL-QATTAN and KOZIN, 2013). SHH induces the expression of secreted proteins and transcription factors such as HOXAl3 and Dl3 in all the digits of hand and feet and HOXD10-12 in the fingers only, except the thumb.

Within the ZPA, ZRA regulatory sequence (ZRS) controls the $\mathrm{SHH}$ activity. ZRS is located is located on chromosome $7 q 26.3$, which is specifically a long-range limb-specific $\mathrm{SHH}$ enhancer (AL-QATTAN and KOZIN, 2013).

\section{Polydactyly of Hand}

Polydactyly of the hand is a common congenital deformity characterised by the presence of one or more supernumerary phalanges and occasionally, extra metacarpals (JIAN, JIANSONG, GUOQIANG et al., 2011). It can be radial (pre-axial), ulnar (post-axial) or central (GRAINNE, 2010). Polydactyly can also be classified as polydactyly type A and type B. In type A, the extra digits contain phalanges, whereas in type $\mathrm{B}$, there is no skeletal structure (GAWLIKOWSKA-SROKA, 2008).

Pre-axial polydactyly is a term coined for a wide spectrum of congenital anomalies found in the radial side of the hand and tibial side of the feet. Materna-Kiryluk, Jamsheer, Wisniewska et al. (2013) have classified hallux polydactyly, triphalangeal thumb, polydactyly of index finger and polysyndactyly as types of pre-axial polydactyly out of which, involvement of the thumb is most frequently encountered (MATERNA-KIRYLUK, JAMSHEER, WISNIEWSKA et al., 2013). Radial polydactyly, a type of pre-axial polydactyly is a component of a syndrome complex and is considered as an autosomal recessive disease (SIQUEIRA, STERODIMAS, BORIANI et al., 2008).
It often presents as an isolated abnormality more commonly in Caucasians (GRAINNE, 2010). It ranges from complete duplication of the thumb to various degrees of splitting. More so in many cases, a small vestigial skin tag may be present of the radial side of the thumb (WATT and KEVIN, 2009). Many cases of radial polydactyly which present as skin tag or bifid thumb may be unilateral and sporadic whereas triphalangeal thumb is usually inherited in autosomal dominant pattern (WATT and KEVIN, 2009).

\section{Anatomy of Radial Polydactyly and its Classification}

Most of radial polydactyly cases have an abnormal osseous anatomy which can be appreciated as bony hypoplasia and abnormally widened and angulated articular surfaces (WATT and KEVIN, 2009). As for the muscular changes, an abnormal connection exists in between the flexor and extensor tendons with the accessory bone (WATT and KEVIN, 2009). In a case of thumb duplication, the abductor pollicis brevis and flexor pollicis brevis insert into the proximal phalanx of the accessory thumb whereas opponens pollicis inserts into the metacarpal. Most of the duplicates have an adequate arterial supply through single digital arteries which may be on the radial or ulnar side or both (WATT and KEVIN, 2009).

Wassel classified polydactyly into seven types based on the anatomic level of duplication and distal to proximal variations as shown in Figure 2. Though it is widely accepted, it has its own limitations in describing the concrete morphology of the duplication (SIQUEIRA, STERODIMAS, BORIANI et al., 2008). Among the different types of Wassel, Type IV is the commonest and type II the least expressed (ANI, 2010).

Hence, Chung, AEK, GONG et al. (2013) have suggested a new classification system based on the anatomic pattern of duplication to facilitate surgical correction of the deformity and to evaluate the outcome (Table 2).

\section{Etiology of Radial Polydactyly}

Scientists have uncovered that majority of congenital anomalies involving the upper limbs occur between the fourth and eighth week of gestation (WATT and KEVIN, 2009). The pathogenesis of radial polydactyly is multifactorial namely, genetic, teratogenic or environmental (KOZIN, 2003). Materna-Kiryluk, Jamsheer, Wisniewska et al. (2013) have confirmed that non-genetic factors play a crucial role in the etiology of non-familial radial polydactyly. A detailed review of the embryology of the upper limb reveals that a case of radial polydactyly is due to ectopic $\mathrm{SHH}$ in the anterior mesoderm. Of various types of expressions, a radial polydactyly due to duplication of a biphalangeal thumb is commonly encountered 


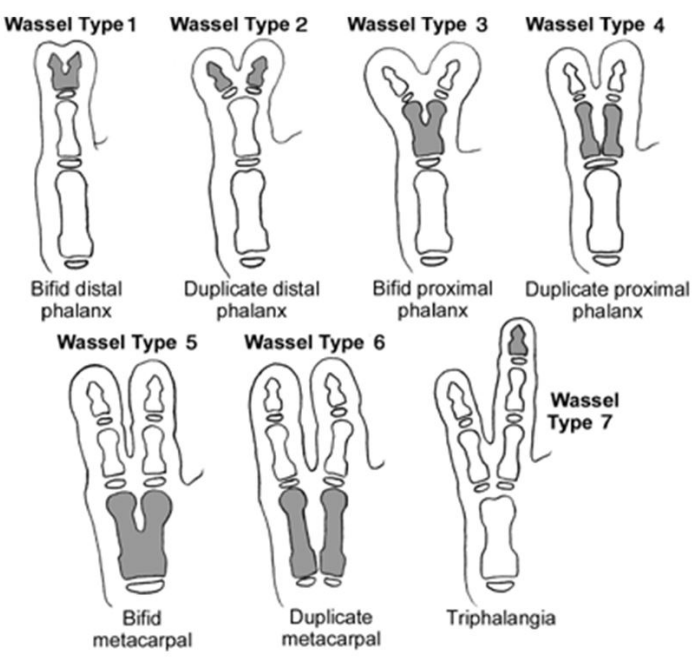

Figure 2. Showing Wassel's classification of radial polydactyly (reproduced from SIQUEIRA, STERODIMAS, BORIANI et al., 2008).

Table 2. Chung et al's classification of radial polydactyly (Extracted from CHUNG, AEK, GONG et al., 2013).

\begin{tabular}{ll}
\hline \multicolumn{1}{c}{ Types } & \multicolumn{1}{c}{ Features } \\
\hline I (joint type) & $\begin{array}{l}\text { The extra digit has its } \\
\text { own joint at its origin }\end{array}$ \\
\hline II (single epiphyseal type) & $\begin{array}{l}\text { The origin of the extra } \\
\text { digit is derived directly } \\
\text { from the common } \\
\text { epiphysis }\end{array}$ \\
\hline III (osteochondroma-like type) & $\begin{array}{l}\text { The origin of the extra } \\
\text { digit resembles an } \\
\text { osteochondroma }\end{array}$ \\
\hline & $\begin{array}{l}\text { The extra digit is } \\
\text { connected to the main } \\
\text { digit by soft tissue alone. }\end{array}$ \\
\hline
\end{tabular}

and, is a representative of a stochastic error due to minor anterior SHH expression more frequently seen in familial cases (MATERNA-KIRYLUK, JAMSHEER, WISNIEWSKA et al., 2013; AL-QATTAN and KOZIN, 2013). Sporadic, isolated cases of radial polydactyly of the thumb is frequently observed in males and occur on the left side and in infants of diabetic mothers and exposed to thalidomide (MATERNA-KIRYLUK, JAMSHEER, WISNIEWSKA et al., 2013). Materna-Kiryluk, Jamsheer, Wisniewska et al. (2013) have demonstrated as low birth weight among infants as the single most influential environmental factor that causes sporadic radial polydactyly. Other positive risk factor for both sporadic and familial cases of polydactyly is confirmed as oligohydramnios but the linking factor between both is yet to be studied (MATERNAKIRYLUK, JAMSHEER, WISNIEWSKA et al., 2013). Though familial cases of polydactylies are inherited, there are various non-similar manifestations in the subsequent generations proving the involvement of additional environmental modifiers that alter the phenotypic expressions of the genetic defects (MATERNA-KIRYLUK, JAMSHEER, WISNIEWSKA et al., 2013).
Taking more serious cases of radial polydactyly such as thumb polydactyly with triphalangism, isolated triphalangeal thumb and thumb triplication into account shows us that they require moderate increase in anterior $\mathrm{SHH}$ expression and are usually related to point mutations in the ZRS leading to moderate gain of function of SHH expression (AL-QATTAN and KOZIN, 2013). Triphalangeal thumb which requires a higher level of SHH is linked to chromosome 7q36 mutation and occurs due to autosomal dominant inheritance (ZUIDAM, ANANTA and HOVIUS, 2008).

\section{Conclusion}

Congenital anomalies are not always familial and are not always related to genetic abnormalities. Radial polydactyly is one such anomaly, whose etiology has an equal share of environmental and genetic factors. This defect is due to the high expression of Sonic hedgehog $(\mathrm{SHH})$ which is normally absent in the radial side of the hand. Though familial cases are reported due to chromosome $7 \mathrm{q} 36$ mutation and occurs due to autosomal dominant inheritance, isolated sporadic cases have a strong environmental influence in the fetus in utero to produce this defect. Further research pertaining to the causal relationship between these environmental factors to the abnormal or excessive expression of $\mathrm{SHH}$ would open up new horizons in morphological development.

\section{References}

AL-QATTAN, MM. and KOZIN, SH. An update on embryology of the upper limb. The Journal of Hand Surgery, 2013, vol. 38, n. 9, p. 1835-1844. PMid:23684522. http://dx.doi.org/10.1016/j. jhsa.2013.03.018.

ANI, CC. Isolated Wassel type II preaxial polydactyly. Jos Journal of Medicine, 2010, vol. 5, n. 1, p. 48-49. http://dx.doi.org/10.4314/ jjm.v5il.62032.

CHUNG, MS., BAEK, GH., GONG, HS., LEE, HJ., KIM, J. and RHEE, SH. Radial polydactyly: proposal for a new classification system based on the 159 duplicated thumbs. Journal of Pediatric Orthopedics, 2013, vol. 33, n. 2, p. 190-196. PMid:23389575. http://dx.doi. org/10.1097/BPO.0b013e3182648ca8.

GAWLIKOWSKA-SROKA, A. Polydactyly and syndactyly as the most common congenital disorders of the limbs. Annales Academiae Medicae Stetinensis, 2008, vol. 54, n. 3, p. 130-133. PMid:19839525.

GRAINNE, B. Congenital hand anomalies. Orthopaedics and Trauma, 2010, vol. 25 , n. 2, p. 143-154.

JIAN, Z., JIANSONG, C., GUOQIANG, Z. and LIPING, Y. Unique case of 11-fingered polydactyly with cleft hand. Journal of Plastic, Reconstructive o Aesthetic Surgery, 2011, vol. 64, n. 5, p. 685-687. PMid:20739235. http://dx.doi.org/10.1016/j.bjps.2010.07.029.

KOZIN, SH. Upper-extremity congenital anomalies. The journal of Bone and Joint Surgery, 2003, vol. 85, n. 8, p. 1564-1576. PMid:12925640. http://dx.doi.org/10.2106/00004623-200308000-00021.

MATERNA-KIRYLUK, A., JAMSHEER, A., WISNIEWSKA, K., WIECKOWSKA, B., LIMON, J., BORSZEWSKA-KORNACKA, M., SAWULICKA-OLESZCZUK, H., SZWALKIEWICZ-WAROWICKA, E. and LATOS-BIELENSKA, A. Epidemiology of isolated preaxial polydactyly type I: data from the Polish Registry of Congenital Malformation (PRCM). BioMed Central Pediatrics, 2013, vol. 13, n. 
26, p. 1-9. PMID: 23421878. http://dx.doi.org/10.1186/14712431-13-26.

PÉREZ-MOLINA, JJ., ALFARO-ALFARO, N., LÓPEZ-ZERMEÑO, MC. and GARCÍA-CALDERÓN, MA. Polydactyly in 26,670 consecutive births. The clinical characteristics, prevalence and risk factors. Boletin Medico del Hospital Infantil de Mexico, 1993, vol. 50, n. 11, p. 803-808. PMid:8274232.

SIQUEIRA, MA., STERODIMAS, A., BORIANI, F. and PITANGUY, I. A 10 -year experience with the surgical treatment of radial polydactyly. Annali Italiani di Chirurgia, 2008, vol. 79, n. 6, p. 441-444. PMid:19354039.
WATT, AJ. and KEVIN, C. Duplication. Hand Clinics, 2009, vol. 25, n. 2, p. 215-227. PMid:19380061. http://dx.doi.org/10.1016/j. hcl.2009.01.001.

ZUIDAM, JM., ANANTA, M. and HOVIUS, SE. Triplicated thumbs: a rarity? Journal of Plastic, Reconstructive \& Aesthetic Surgery, 2008, vol. 61, n. 9, p. 1078-1084. PMid:17822968. http://dx.doi. org/10.1016/j.bjps.2007.02.034.

Received 13 July 2015 Accepted 18 October 2016 